Agro-Science Journal of Tropical Agriculture, Food, Environment and Extension Volume 11 Number 1 January 2012 nn $21-32$

ISSN 1119-7455

\title{
CHARACTERISTICS AND CLASSIFICATION OF SOILS ON QUATERNARY COVERSAND IN SOKOTO-RIMA BASIN, NIGERIA
}

\author{
Yakubu $^{1}$ M. and Ojanuga ${ }^{2}$ A.G. \\ ${ }^{1}$ Faculty of Agriculture, Ibrahim Badamasi Babangida University, Lapai, Niger State, Nigeria \\ ${ }^{2}$ Department of Soil Science and Agricultural Engineering, Usmanu Danfodiyo University, \\ Sokoto, Nigeria
}

\begin{abstract}
A study was conducted to characterize and classify the soils on quaternary parent materials (Sangiwa, Sokoto, and Illela coversand) of Sokoto-Rima river basin area of Sokoto state. Areas covered with the coversand were identified using geologic map of the Sokoto-Rima basin followed by ground truthing. Soils from different coversand were examined using auger in order to ascertain relationships between coversand and geologic formations. Six pedons, two each from the three different coversand were dug and described. Morphological properties of the soils revealed a dominant spectral colour hue of 7.5YR and 10YR with a weak to moderate fine-medium subangular block at the subsurface and subsoil and single grain structure at the surface. The soils are predominantly sandy in texture with sand weighted average values of $>90 \%$ in Sokoto and Illela coversand and $>80 \%$ in Sangiwa coversand. The soils were acidic with $\mathrm{pH}$ values ranging from 4.6 to 5.4. Organic matter, exchangeable bases, CEC and base saturation were generally low indicating low fertility status of the soils. The dominant mineral found in the soils is quartz with traces of kaolinite. The soils were classified as Ustic Quartzipsamment (Sokoto and Illela coversand) and Typic Ustipsamment (Sangiwa coversand) according to the USDA Soil Taxonomy System and correlate with Haplic and Dystric Arenosols in the World Reference Base (WRB) for soil resources system. The soils may not be suitable for irrigated agriculture due to their coarsed texture and thus suitable for rain-fed agriculture.
\end{abstract}

Keywords: Coversand, Characterization, Classification, Quaternary, and Geologic formation

\section{INTRODUCTION}

Sedimentary rocks of Cretaceous and Tertiary ages are the major geological formation of the present Sokoto State. The rocks of the sedimentary deposits are rather complex being composed of deposits laid down in three main phases; continental Pre-Maastrichtian, and Tertiary along with intervening marine Maastrichtian to Paleocene phase and recent drift materials overlying surfaces (Jones, 1948; Sombroek and Zonneveld, 1971). Gundumi, Illo, and Rima group (Wurno, Taloka and Dukamaje) constitute the Cretaceous sedimentary rocks, while Sokoto group (Dange, Kalambaina and Gwandu formations) represents the Tertiary sedimentary rocks (FDALR, 1985).The Cretaceous and the Tertiary rocks were deposited as sediments in a synclinical basin, active from the late Cretaceous to the early Tertiary. The deposits are mostly conformable and without folding, and show a regular slight dip of about $3.5 \mathrm{~m}$ per $\mathrm{km}$ to the north- northwest. In general the various deposits are thickest in the north; they thin away towards the Southwest, to the extent that south of the lower Zamfara River the strata are very near to each other or even lacking (Sombroek, 1971).

In the Quaternary period, deposition of aeolian materials over the sedimentary deposits took place. There are five different types of deposits, which, because of their geography and granulometry are undoubtedly aeolic in character. These deposits are Sangiwa, Sokoto, Zurmi, Illela and Funtua deposits. Those found at the northern part of the basin and occurring in the study area are, Sangiwa, Sokoto and Illela (Sombroek and Zonneveld, 1971). Sangiwa coversand deposit is found in the central northeastern part of the basin (Isa, Lamba-Tureta) and in the northwestern part (Tangaza).The deposit occurs uniformly over wide stretches of most of the flattened parts of the area with either the Cretaceous Gundumi or Tertiary Gwandu deposits either at shallow depth or 
outcropping. The Sokoto coversand is found in the northwest central part of the basin. Marked concentrations occur around Sokoto and Tambuwal towns and north of Lema. The deposit occurs over wide stretches in the area of the Tertiary Kalambaina- Dange deposit, and is scattered in the area of the Tertiary upper Gwandu deposits. It also occurs very locally in the area of the Cretaceous Rima and Gundumi deposits. The Illela coversand are found only in small area of Sokoto town, near the frontier with Niger Republic (Raka, Illela, and Gada). The deposit occurs as a continuous cover near tableland outcrops of the middle Gwandu, as discontinuous stretches running roughly East-west on plateau and of the Kalambaina formation and as patches near plinthite outcrops of the upper Gwandu and the Dukamaje formations. The thickness varies from $0.5 \mathrm{~m}$ in the slacks of the dunes on the Kalambaina plateau land to more than $30 \mathrm{~m}$ near scarps of the middle or upper Gwandu (Sombroek and Zonneveld, 1971).

Parent materials control to a greater extent the direction and rates of soil genesis by controlling the amounts and types of mineral transformations that may take place and the nature of eluviation and illuviation phenomena (Fanning and Fanning, 1989). Parent materials influence soil formation by their different rates of weathering, their nutrients and the dominant particle-size they contain. The less developed a soil is, the greater will be the effect of parent material on the properties of the soil. Even the properties of welldeveloped soils will be greatly influenced by the parent material; for instance, clay is formed by a high percentage of decomposable dark (ferromagnesian) minerals and by less quartz content. Different soils will result from different types of parent material (Esu, 1999).

Soils on coversand constitute part of the arable land in Sokoto State (FDALR, 1985; Sombroek and Zonneveld, 1971; Zonneveld, 1999) and crops grown include cowpea, millet, cassava etc. The soils have been described as the poorest soils in the state in terms of fertility rating (Yakubu and Singh, 2001; Yakubu et al., 2006). There is a general dearth of pedological information about the soils on coversand. Some few related researches conducted on sand dunes of Sokoto state include those of Raji et al. (1997); Yakubu and Singh (2001) and Yakubu et al. (2006). Owing to this, amongst others, a study was conducted to characterize and classify soils on coversand in Sokoto-Rima basin part of Sokoto State.

\section{MATERIALS AND METHODS Study Area}

The study was conducted in areas covered with the coversand in Sokoto-Rima Basin part of Sokoto State (Figure 1). It is located between latitudes $11^{\circ}$ and $16^{\circ}$ north and longitudes $4^{\circ}$ and $8^{\circ}$ east. The total area is approximately 193,000 $\mathrm{km}^{2}$ and is distributed between Nigeria and the Niger Republic. Less than half of the basin area, approximately $90,000 \mathrm{~km}^{2}$ is located in Nigeria and only this area is significant from a hydrological point of view (Zonneveld, 1999).

Geological map was used to identify areas covered with the different coversand. Sangiwa, Sokoto and Illela coversands cover areas underlain by Gundumi, Kalambaina-Dange and Dukamaje formations respectively. The climate is hot, semi-arid tropical or type Aw in Koppen climatic classification (Sombroek and Zonneveld, 1971) with Sudan savanna vegetation (Deleeuw, 1966). The mean annual rainfall is about $600 \mathrm{~mm}$ falling between June and September, the rest of the year being characterized by a pronounced dry season (Kowal and Knabe, 1972). The dominant underlying geology is Cretaceous and Tertiary sediments (Jones, 1948; Pugh and King, 1952; Kogbe, 1976).

\section{Field study}

Areas covered with the coversand were identified using the geologic map of the SokotoRima basin (Figure 1) followed by ground truthing. Soils from different coversand were examined using auger in order to ascertain relationships between coversand and other geologic formations. Six profiles pits (pedons), two each from the three different coversand were dug. Profile description was done according to the profile description by Schoeneberger et al. (2002). Samples were collected from the pedogenic horizons for laboratory analyses.

\section{Laboratory Analysis}

Physical and chemical properties of the soils were determined and the methodologies employed are as given below.

\section{Particle size determination}

The proportions of the different soil separates from each horizon were determined by the hydrometer method (Gee and Bauder, 1986).

\section{Bulk density determination}

Bulk density was determined by drying the undisturbed core sample to a constant weight at $105^{\circ} \mathrm{C}$ and dividing the oven-dried weight of the soil sample by its volume according to the 
formulae: $D b=\frac{M}{V}$ Where, $\mathrm{Db}=$ bulk density, $\mathrm{M}=$ oven-dried weight of soil and $\mathrm{V}=$ volume of core sampler.

\section{Soil Reaction}

Soil $\mathrm{pH}$ was measured in a 1:1 soil-water and $1: 1 \mathrm{~N}$ soil- $\mathrm{KCl}$ with glass electrode $\mathrm{pH}$ meter (Mclean, 1982).

\section{Organic carbon determination}

Organic carbon content of the samples was determined by the chromic modified WalkleyBlack method (Nelson and Sommers, 1982).

\section{Cation exchange capacity (CEC) and Effective cation exchange capacity (ECEC)}

The cation exchange capacity (CEC) of the soils was determined by saturating the soil with normal neutral ammonium acetate solution and washing the excess ammonium with alcohol. The samples were later distilled and titrated against standard hydrochroloric acid using auto analyzer (Lavkulich, 1981).

Effective CEC was determined by summing the exchangeable bases and extractable acidity

\section{Exchangeable bases}

The exchangeable bases were determined using the ammonium acetate extract from CEC determination. Sodium and potassium were determined using the flame photometer while calcium and magnesium were determined using the atomic absorption spectrophotometer (AAS) (Jones, 2001).

\section{Extractable acidity}

Soil samples were leached with potassium chloride solution. The aluminum (Al) and hydrogen $(\mathrm{H})$ in the leachate were titrated against standard $\mathrm{NaOH}$ solution using phenolphthalein as indicator. The $\mathrm{NaOH}$ used corresponds to the melliequivalents of aluminum plus hydrogen. The solution was brought back to the original colourless condition and subsequently titrated against hydrochloric acid to determine the amount of aluminum (Jones, 2001). The exchangeable acidity was determined only for samples with $\mathrm{pH}$ (in $\mathrm{H}_{2} \mathrm{O}$ ) $<5.5$.

\section{Base saturation}

Base saturation was determined by dividing the total exchangeable bases by $\mathrm{NH}_{4} \mathrm{OAc}$ cation exchange capacity and expressed as a percentage.

\section{X-Ray diffraction analysis}

The $<2 \mathrm{~mm}$ air-dried samples (fine-earth) were examined with an X-ray diffractometer (Rigaku Miniflex type) and Ni-filtered $\mathrm{Cu}-\mathrm{K} \alpha$ radiation generated at $40 \mathrm{KV}$ and $30 \mathrm{~mA}$. The XRD patterns were recorded ranging from $3-60^{\circ}$ (20) with a scanning speed of $20^{\circ} / \mathrm{min}$. The identification and semi-quantitative determination of the mineral are based on the differences of reflection patterns from the air-dried samples (Johns et al., 1954; Brindley, 1980).

\section{RESULTS AND DISCUSSION}

The morphological, physical, chemical and mineralogical properties of the soils are presented in Tables 1, 2, 3 and 4 respectively.

\section{Morphological properties}

Summary of the morphological properties of the soils is presented in Table 1. Horizon sequences in all pedons are the same, as Ap or A horizon overlies $\mathrm{AC}$ and or $\mathrm{C}$ horizon. The nature of these horizon sequences is indicative of young soil in all the pedons. Soil colour in soils of Sangiwa coversand (Pedon 1) is brown (7.5YR 5/4) in the surface grading to yellowish red (5YR 5/8) and strong brown (7.5YR 5/8) in the subsurface and subsoil. In pedon 2 the soils are light yellowish brown (10YR 6/4) in the surface and grading to yellowish brown (10YR 5/4) in the subsoil. In soils of Sokoto coversand (Pedon 3 ) the colour is dark brown (5YR 4/6) in the surface and subsurface and yellowish red (5YR 5/8) in the subsoil and the $\mathrm{C}$ horizon. In the surface and the $\mathrm{C}$ horizons of the pedon 4, the soil showed a predominant hue colour of 10YR while in the subsoil a hue of 7.5YR predominates. The colour on soils of Illela coversand (pedon 5 and 6 ) is strong brown (7.5YR 5/6) in the surface horizon changing to dark brown (7.5YR 3/4) and brown (10YR 5/3) in the subsoil and $\mathrm{C}$ horizons. Differences in organic matter content and parent materials may have been responsible for the differences in soil colour. The soils were structurally weak. The predominant structure is weak to moderate fine subangular blocky in the subsurface. Consistence was loose in most surface horizons and friable in subsurface and subsoil. 


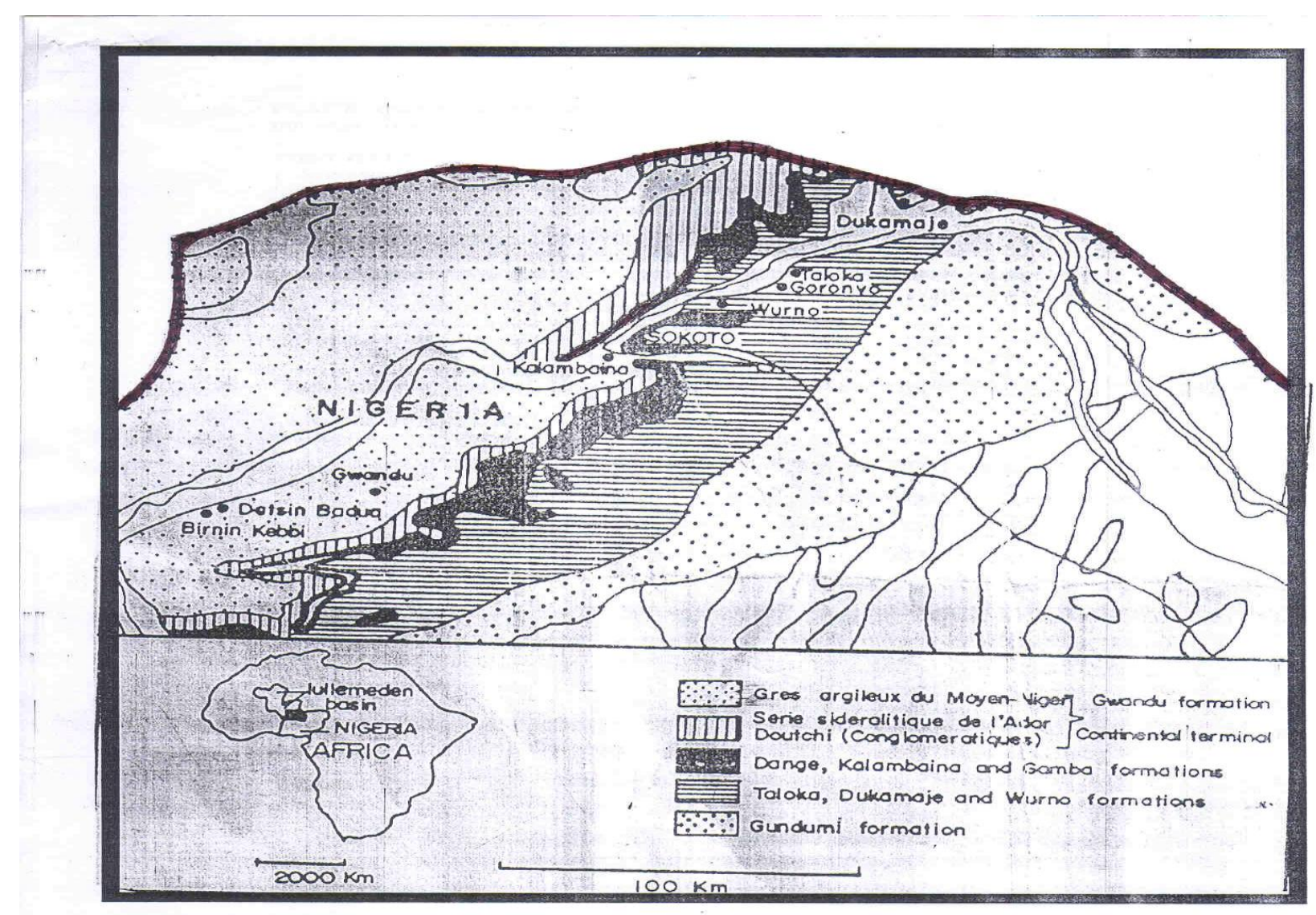

Figure 1. Map of Sokoto-Rima Basin showing the geological materials overlain by coversand in the study area 
Table 1. Morphological Properties of the coversand

\begin{tabular}{|c|c|c|c|c|c|c|c|}
\hline Pedon & Horizon & Depth (cm) & Colour* & Structure* & Consistence* & $\begin{array}{c}\text { Other } \\
\text { Features }\end{array}$ & Boundary \\
\hline \multirow{5}{*}{1 (Sangiwa) } & \multicolumn{6}{|c|}{ Typic Ustipsamments } & \\
\hline & A & $0-22$ & $7.5 \mathrm{YR} 4 / 5$ & $1 \mathrm{msbk}$ & Lo & $1 \mathrm{fnr}$ & CS \\
\hline & $\mathrm{AC}$ & $22-55$ & $5 Y R 4 / 6$ & $1 \mathrm{msbk}$ & Lo & $1 \mathrm{fnr}, \mathrm{ch}$ & DS \\
\hline & $\mathrm{C} 1$ & $55-135$ & 5YR 5/8 & $1 \mathrm{msbk}$ & Lo & $1 \mathrm{fnr}$ & DS \\
\hline & $\mathrm{C} 2$ & $135-205$ & 7.5 YR 5/8 & $1 \mathrm{msbk}$ & Lo & $1 \mathrm{fnr}$ & \\
\hline \multirow[t]{5}{*}{2 (Sangiwa) } & \multicolumn{6}{|c|}{ Typic Ustipsamments } & \\
\hline & Ap & $0-55$ & 10YR 6/4 & $1 \mathrm{msbk}$ & Lo & $3 \mathrm{fnr}$, ch & AW \\
\hline & $\mathrm{AC} 1$ & $55-95$ & 10YR 5/4 & $1 \mathrm{msbk}$ & $\mathrm{Fr}$ & $3 \mathrm{fnr}, \mathrm{ch}$ & DS \\
\hline & $\mathrm{AC} 2$ & $95-130$ & 10YR 5/4 & $1 \mathrm{msbk}$ & $\mathrm{Fr}$ & $3 \mathrm{fnr}$, ch & DS \\
\hline & $\mathrm{C}$ & 130-201 & 10YR 5/3 & $1 \mathrm{msbk}$ & $\mathrm{Fr}$ & $1 \mathrm{fnr}$ & \\
\hline \multirow[t]{7}{*}{3 (Sokoto) } & \multicolumn{6}{|c|}{ Ustic Quartzipsamments } & \\
\hline & Ap & $0-30$ & $5 Y R 4 / 6$ & $0 \mathrm{Sg}$ & Lo & $3 \mathrm{fnr}$, ch & $\mathrm{CS}$ \\
\hline & AC & $30-60$ & $5 Y R 4 / 6$ & $1 \mathrm{fsbk}$ & Vfr & $1 \mathrm{fnr}, \mathrm{ch}$ & $\mathrm{CS}$ \\
\hline & $\mathrm{C} 1$ & $60-120$ & $5 Y R 4 / 6$ & $1 \mathrm{fsbk}$ & Vfr & $1 \mathrm{fnr}, \mathrm{ch}$ & $\mathrm{CS}$ \\
\hline & $\mathrm{C} 2$ & $120-150$ & 5YR 5/8 & $1 \mathrm{fsbk}$ & Vfr & $\mathrm{Ch}$ & $\mathrm{CS}$ \\
\hline & $\mathrm{C} 3$ & $150-180$ & 5YR 5/8 & $1 \mathrm{fsbk}$ & Vfr & - & $\mathrm{CS}$ \\
\hline & $\mathrm{C} 4$ & $180-202$ & $5 Y R 5 / 8$ & $1 \mathrm{fsbk}$ & Vfr & - & \\
\hline \multirow[t]{6}{*}{4 (Sokoto) } & \multicolumn{6}{|c|}{ Ustic Quartzipsamments } & \\
\hline & Ap & $0-32$ & 10YR 5/4 & $0 \mathrm{Sg}$ & Lo & $1 \mathrm{fnr}, \mathrm{ch}$ & $\mathrm{CS}$ \\
\hline & $\mathrm{AC}$ & $32-60$ & 10YR 4/6 & $1 \mathrm{fsbk}$ & $\mathrm{Fr}$ & $3 \mathrm{fnr}$, ch & $\mathrm{CS}$ \\
\hline & $\mathrm{C} 1$ & $60-120$ & 7.5YR 5/6 & $1 \mathrm{fsbk}$ & Vfr & $3 \mathrm{fnr}, \mathrm{ch}$, & $\mathrm{CS}$ \\
\hline & $\mathrm{C} 2$ & $120-160$ & 7.5YR 5/8 & $1 \mathrm{fsbk}$ & Vfr & ch, & $\mathrm{CS}$ \\
\hline & $\mathrm{C} 3$ & $160-201$ & 10YR 6/6 & $1 \mathrm{fsbk}$ & Vfr & & $\mathrm{CS}$ \\
\hline \multirow[t]{6}{*}{5 (Illela) } & \multicolumn{6}{|c|}{ Ustic Quartzipsamments } & \\
\hline & Ap & $0-18$ & $7.5 Y R 5 / 6$ & $0 \mathrm{Sg}$ & Lo & $1 \mathrm{fnr}, \mathrm{ch}$ & $\mathrm{CW}$ \\
\hline & $\mathrm{AC} 1$ & $18-32$ & 7.5YR 4/4 & $1 \mathrm{fsbk}$ & Vfr & $1 \mathrm{fnr}$ & $\mathrm{CW}$ \\
\hline & $\mathrm{C} 1$ & $32-95$ & $5 Y R 3 / 4$ & $1 \mathrm{fsbk}$ & $\mathrm{Fr}$ & $1 \mathrm{fnr}, \mathrm{cho}$, po & CS \\
\hline & $\mathrm{C} 2$ & $95-150$ & $7.5 Y^{3} 3 / 4$ & $1 \mathrm{fsbk}$ & $\mathrm{Fr}$ & - & CS \\
\hline & $\mathrm{C} 3$ & $150-210$ & $7.5 \mathrm{YR} 4 / 6$ & $1 \mathrm{fsbk}$ & $\mathrm{Fr}$ & - & \\
\hline \multirow[t]{6}{*}{6 (Illela) } & \multicolumn{5}{|c|}{ Ustic Quartzipsamments } & & \\
\hline & Ap & $0-40$ & 7.5YR 5/6 & $0 \mathrm{Sg}$ & Lo & $2 \mathrm{fnr}$, ch & $\mathrm{CS}$ \\
\hline & $\mathrm{AC} 1$ & $40-100$ & $10 \mathrm{YR} 4 / 2$ & $2 \mathrm{fsbk}$ & $\mathrm{Fr}$ & 1fnr, cho & $\mathrm{CW}$ \\
\hline & $\mathrm{C} 1$ & $100-130$ & $7.5 \mathrm{YR} 5 / 2$ & $2 \mathrm{fsbk}$ & Fr & $1 \mathrm{fnr}$ & $\mathrm{CW}$ \\
\hline & $\mathrm{C} 2$ & $130-200$ & $10 \mathrm{YR} 5 / 3$ & $2 \mathrm{fsbk}$ & $\mathrm{Fr}$ & - & $\mathrm{CW}$ \\
\hline & $\mathrm{C} 3$ & $200-220$ & 10 YR $8 / 3$ & $2 \mathrm{fsbk}$ & $\mathrm{Fr}$ & - & \\
\hline
\end{tabular}

*= Determined at natural moisture condition, Note: symbols/code according to Schoeneberger, et al., 2002

Structure: $0=$ structureless, $1=$ weak, $2=$ moderate, $3=$ strong, $\mathrm{sg}=$ single grain, csbk=coarse subangular blocky, fsbk, fine subangular blocky, $\mathrm{m}=$ massive,; Consistence: $\mathrm{lo}=\mathrm{loose}, \mathrm{fr}=$ friable, vfr=very friable; Roots: $1=\mathrm{few}, 2=$ moderate, $3=$ many, fnr=fine roots, co=coarse roots; sh=shale, ch=channel $\mathrm{Fe}=$ ironstone crust, $\mathrm{Fec}=$ iron concretion; Boundary; $\mathrm{A}=$ abrupt, $\mathbf{C}=$ clear, $\mathbf{G}=$ gradual, $\mathbf{S}=$ smooth,

W=wavy, 


\section{Physical Properties of the Soils}

Results of the physical properties of the soils are presented in Table 2. Soils on Sangiwa coversand have sand weighted average values of 86 and $91 \%$ for pedons 1 and 2 respectively. Pedons 3 and 4 are generally sandy (sand range from 90 to $99 \%$ ) because the parent materials are aeolian in origin (Sokoto coversand). Pedons 5 and 6 (Illela coversand) have sand weighted average of $96 \%$ and $97 \%$ respectively.

Bulk density weighted values ranged from 1.6 to $1.8 \mathrm{Mg} / \mathrm{m}^{3}$ in all the pedons. Relatively high bulk density values of the soils may be due to compaction caused by grazing animals and the use of heavy machinery during land preparation. Bulk density $>1.6 \mathrm{Mgm}^{-3}$ may inhibit root growth and development and also slow movement of water. This property may limit the use of these soils for agriculture. Good plant growth is best in bulk densities below $1.4 \mathrm{Mg} / \mathrm{m}^{3}$ for clay soil and 1.6 $\mathrm{Mg} / \mathrm{m}^{3}$ for sands (Donahue et al., 1990). Consequent upon this, the bulk density values of the soils may therefore be a problem to crop growth.

Porosity values ranged from $62 \%$ to $69 \%$ in pedons 1 and 2 (Sangiwa coversand), $62 \%$ to $65 \%$ in pedons 3, 4, 5 and 6 (Sokoto and Illela coversand). The porosity values were high in all the pedons and could favour good aeration and free water movement in the soils. The high porosity values of the soils could be attributed to its sandy nature.

Average value of the silt/clay ratio is 1.3 in pedons 1 and 2 (Sangiwa coversand), while in Sokoto coversand (Pedons 3 and 4) and Illela coversand (pedons 5 and 6 ), it ranged from 1.3 to 1.5 and 0.5 to 1.0 , respectively.

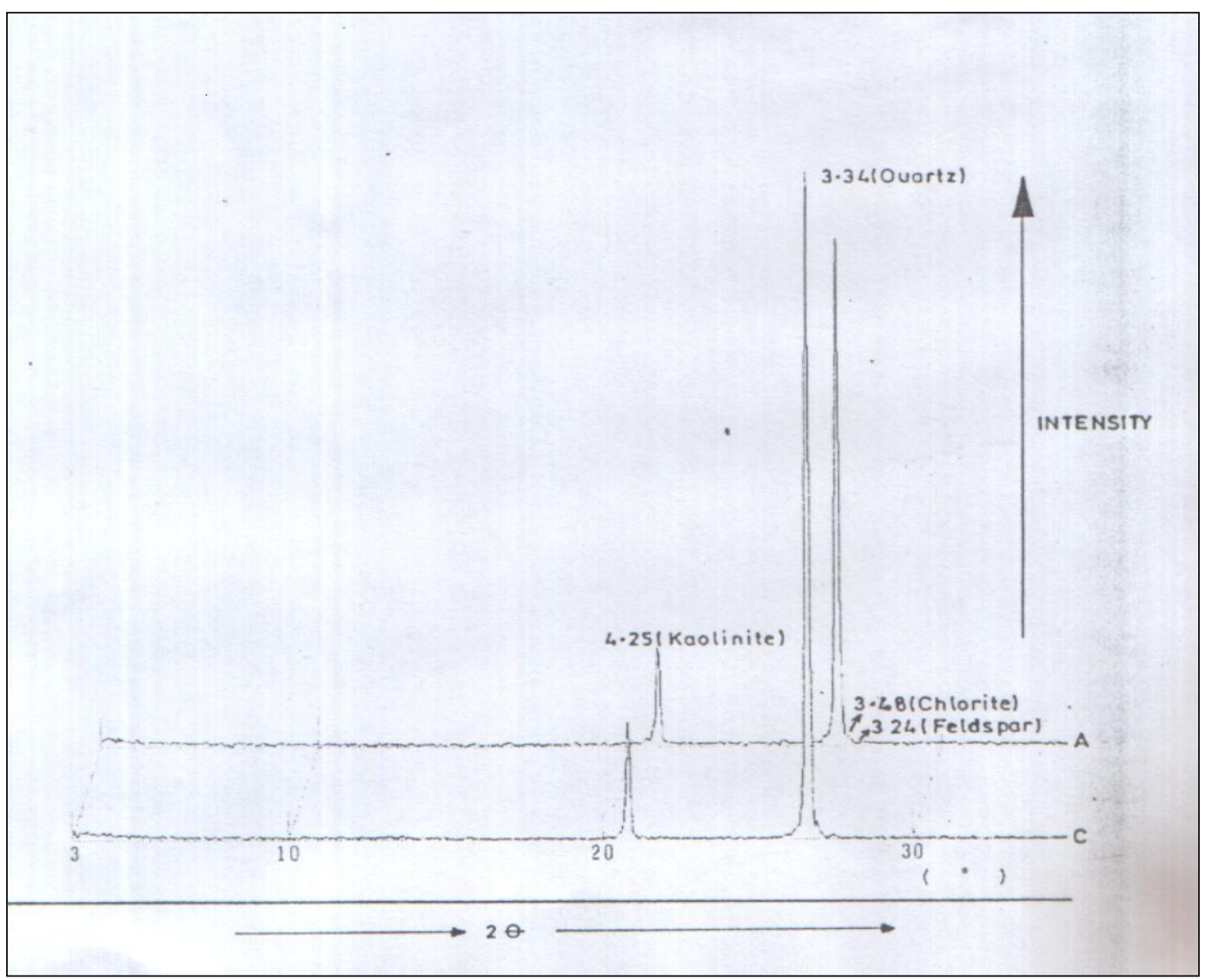

Figure 2. X-ray diffraction pattern of the fine-earth fraction $(<2 \mathrm{~mm})$ of soils on Sangiwa coversand 
Table 2. Physical Properties of the Coversand

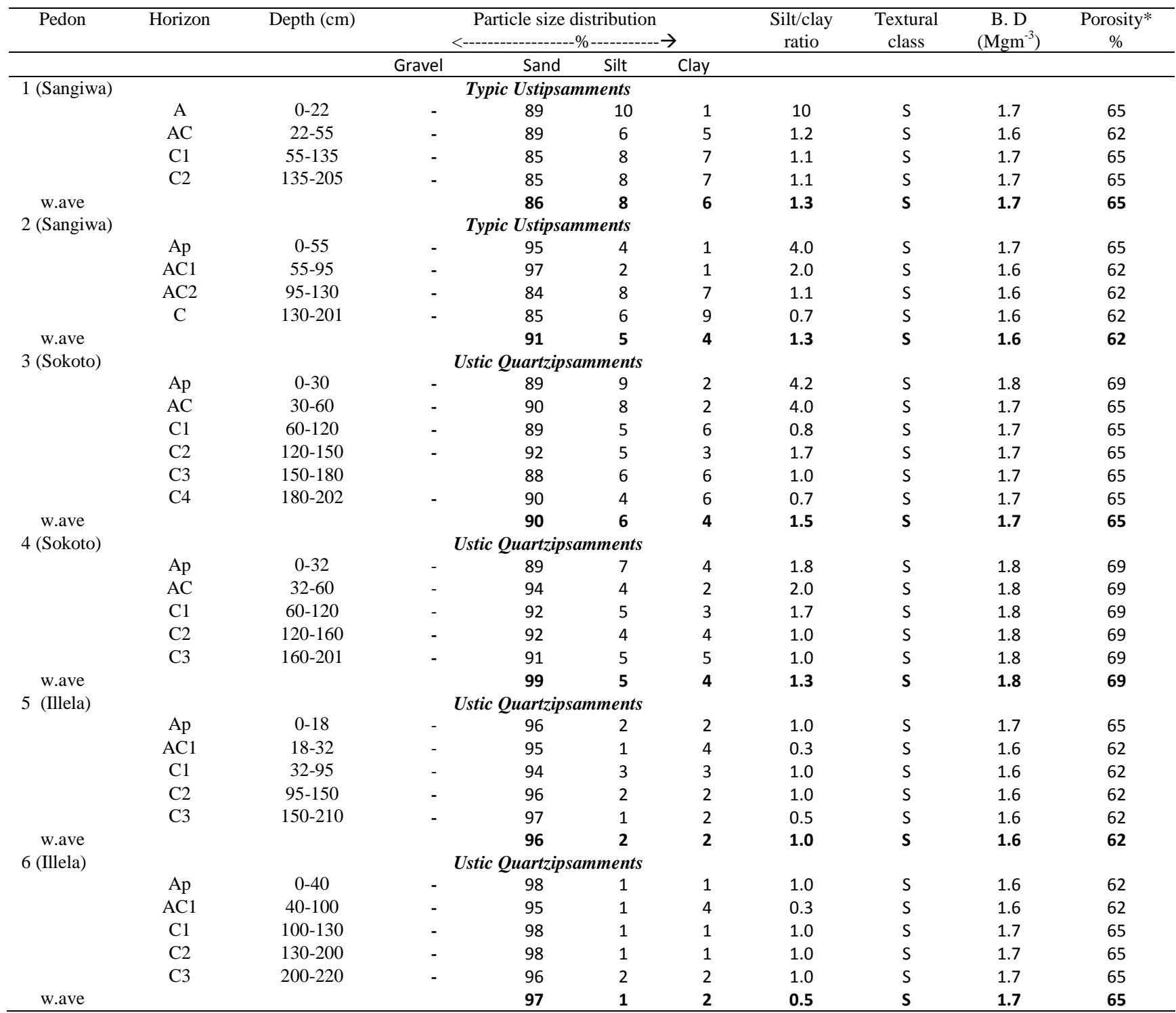

Silt/clay ratio is an important criterion used in the classification of tropical soils. It is also used in the evaluation of clay migration, stage of weathering and age of parent material and soils (Nwaka, 1990). The more highly weathered a soil is the lower the silt fraction. Therefore, soils with silt/clay ratio of less than 0.15 are regarded as highly weathered and old while soils with silt/clay ratio greater than 0.15 are young (Van Wambeke, 1962). Results of this study show that, all the soils have silt/clay ratio above 0.15 or 0.25 indicating that the soils are young with high degree of weathering potential. Silt/clay ratios are relatively higher in the surface and subsurface horizons and decrease with increase in pedon depth. Ayolagha
(2001) obtained similar results from meanders belt soils of the Niger Delta region of Nigeria. Ashaye (1969) also reported similar results with highest values in the surface horizons for well-drained soils. The decrease in silt/clay ratio with depth indicates that subsoils horizons are more weathered than surface horizons. Nwokocha et al. (2003) reported that decreasing silt/clay ratio with depth suggests increased weathering of silt to clay with depth. 


\section{Chemical Characteristics of the Soils}

Results of the chemical properties of the soils are presented in Table 4.

\section{Soil Reaction}

The soil $\mathrm{pH}\left(\mathrm{H}_{2} \mathrm{O}\right)$ varie from very strongly acid to strongly acid (4.4 to 5.4) in all the pedons and in $1 \mathrm{~N} \mathrm{KCl}$, it ranged from 3.4 to 4.8 (Table 3). The $\mathrm{pH}$ in water is found to be higher than $\mathrm{pH}$ in $\mathrm{KCl}$ and thus $\Delta \mathrm{pH}$ is positive. The exchange sites would therefore be negatively charged and will attract a lot of cations for plant nutrition. $\mathrm{pH}$ was observed to increase or decrease irregularly with increasing depth of profile. Low $\mathrm{pH}$ indicates that the soils have been subjected to a longer period of leaching. Soils derived from highly siliceous sandstone are very acidic as stated by Esu (1999). Sombroek and Zonneveld (1971) and Zonneveld (1999) who classified soils of the general area as "Red Acid Soils" have confirmed the acidic nature of these soils.

\section{Organic matter}

Organic matter was generally low in the soils and ranged between $0.12 \%$ and $1.24 \%$ in the soils (Table 3). Organic matter was observed to decrease with increasing depth of profile. The generally low organic matter content in the area has been attributed to rapid decomposition and mineralization of organic materials contributed by sparse vegetation in the hot semiarid climate as promoted by the high radiation (Agbu and Ojanuga, 1989). Another factor is the frequent burning of farm residues commonly carried out by farmers in the general area which tends to destroy much of the organic materials that could have been added to the soil (Yakubu, 2001).

\section{Exchangeable bases}

Calcium and magnesium were the predominant basic cations in the soils and ranged from 0.14 to $0.88 \mathrm{cmol}(+) \mathrm{kg}^{-1}$ and 0.01 to 0.32 cmol (+) $\mathrm{kg}^{-1}$, respectively. Exchangeable potassium and sodium were generally low compared to calcium and magnesium. Values as high as $0.12 \mathrm{cmol}(+) \mathrm{kg}^{-1}$ for potassium and 0.06 $\mathrm{cmol}(+) \mathrm{kg}^{-1}$ for sodium were recorded in the soils . Exchangeable bases in the soils were generally low and this could be attributed to the sandy nature of the soils in which leaching of the available bases is prominent.

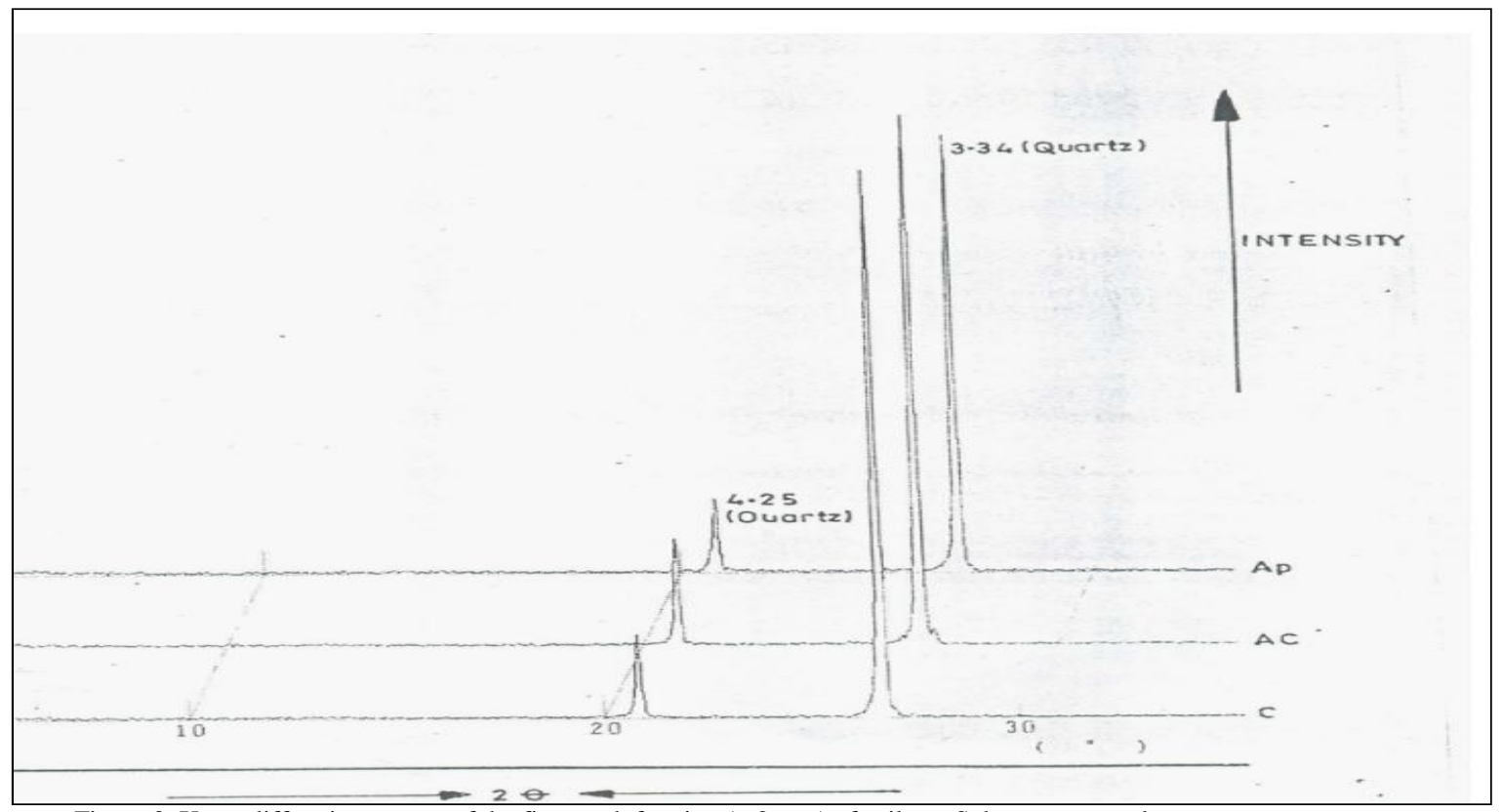

Figure 3. X-ray diffraction pattern of the fine-earth fraction $(<2 \mathrm{~mm})$ of soils on Sokoto coversand 
Table 3 Chemical Properties of the soils on Coversand

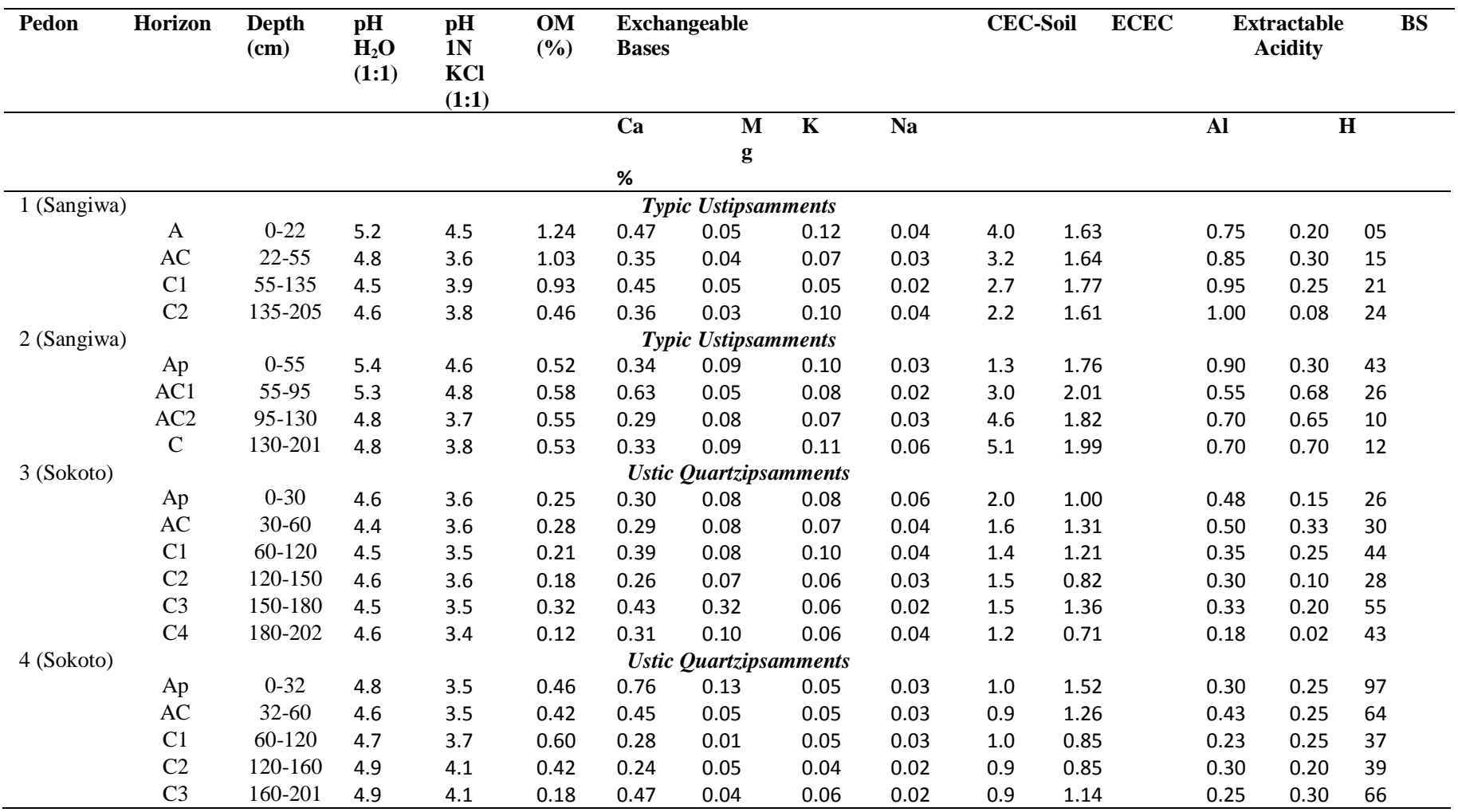

$\mathbf{E C E C}=$ Effective cation exchange capacity, $\mathbf{O M}=$ organic matter, $\mathbf{B S}=$ Base Saturation, matter, $\mathbf{B S}=$ Base Saturation ,

Cation exchange capacity (CEC) and Effective cation exchange capacity (ECEC)

The CEC of the soils ranged from 0.9 to $14.0 \mathrm{cmol} \mathrm{kg} \mathrm{kg}^{-1}$ in all the soils. Cation exchange capacity of the soils was generally low. The low cation exchange capacity in soils of the tropics has been attributed to the nature of clay minerals (kaolinite) (Juo and Moorman, 1981; Opuwaribo and Odu, 1978). Organic matter content of soils which normally influences the CEC was generally low and therefore the CEC values could not be attributed to the amount of organic matter.

The effective cation exchange capacity (ECEC) of the soil was also low, an indication that the soils at their natural $\mathrm{pH}$ levels remain low in CEC indicating a low capacity of the soils to retain nutrients.

\section{Extractable acidity}

Extractable acidity is relatively higher than exchangeable bases in all the soils of the different coversand. Extractable Al ranged from 0.18 to $0.90 \mathrm{cmol}(+) \mathrm{kg}^{-1}$ while extractable $\mathrm{H}$ ranged from 0.02 to $0.68 \mathrm{cmol}(+) \mathrm{kg}^{-1}$. High extractable $\mathrm{Al}$ in soils is an indication of significant amount of acidic cations on the soil exchangeable complex.

\section{Base saturation}

Base saturation values ranged from $05 \%$ to $43 \%$ in soils derived from Sangiwa coversand (pedons 1 and 2), $26 \%$ to $97 \%$ in soils derived from Sokoto coversand (pedon 3 and 4) and $14 \%$ to $75 \%$ in soils derived from Illela coversand (pedons 5 and 6) (Table 3). The low base saturation (average of $<50 \%$ ) in the soils is an indication of low fertility level (FAO, 1998). In general the soils of the coversand have a low base saturation, an indication of leaching of available bases.

\section{Mineralogy of the Soils}

Results of mineralogy of the air-dried fine earth fraction ( $<2 \mathrm{~mm}$ separate) of soils on Sangiwa (pedon 2) and Sokoto coversand (pedon 3 ) is summarized in Table 4 and the peaks are shown as Figures 2 and 3 . In pedon 2 (Sangiwa coversand), the quartz mineral predominates while kaolinite is in trace amount. In addition to 
Table 4. Mineralogical composition by $\mathrm{X}$-ray diffraction of the fine-earth samples of Sangiwa and Sokoto Coversand

\begin{tabular}{lllllll}
\hline Pedon & Horizon & $\begin{array}{l}\text { Depth } \\
\text { (cm) }\end{array}$ & Qz & Kao & Fld & Chl \\
\hline 2 (Sangiwa) & & & & & & \\
& Ap & $0-55$ & 94 & - & 2 & - \\
& C & $130-201$ & 95 & 2 & & - \\
3 (Sokoto) & & & & - & - \\
& Ap & $0-30$ & $\geq 97$ & $\operatorname{Tr}$ & - & - \\
& AC & $30-60$ & $\geq 97$ & $\operatorname{Tr}$ & & - \\
& C3 & $150-180$ & $\geq 98$ & $\operatorname{Tr}$ & &
\end{tabular}

Table 5. Correlation between US Soil Taxonomy and World Reference Base (WRB) for Soil Resources

\begin{tabular}{lllll}
\hline \multirow{2}{*}{ Pedon } & \multicolumn{2}{l}{ US Soil Taxonomy } & WRB & Soil unit \\
\cline { 2 - 5 } & Soil order & Subgroup & Soil group & Arenosols \\
\hline $1 \& 2$ (Sangiwa) & Entisols & Typic Ustipsamments & Arenosols & Haplic Arenosols \\
& & & Arenosols & Haplic Arenosols \\
\hline
\end{tabular}

kaolinite and chlorite, feldspar was identified in the surface (A) and $\mathrm{C}$ horizon and was indicated by a peak at $3.24 \mathrm{~nm}$ (Figure 2). Quartz ranges from $94 \%$ to $95 \%$ in the soils (Table 4). Feldspar mineral makes up about $2 \%$ of the total mineral identified, while chlorite is between 2 and $3 \%$. In pedon 3 , (Sokoto coversand) quartz is the only mineral identified in all the horizons with peaks at $3.34 \mathrm{~nm}$ and $4.46 \mathrm{~nm}$ (Figure 3). The quartz mineral ranges from $\geq 97$ to $\geq 99 \%$ in the soils (Table 4). Kaolinite is in trace amount in the soils. Quartz is the predominant mineral identified in all the soils. Raji et al. (1997) reported similar results in a study conducted on sand dunes around Sokoto

\section{Soil Classification}

The soils are classified at the lowest level of categorization according to USDA Soil Taxonomy (Soil Survey Staff, 2003) and correlated with the World reference base for soil resources (FAO, 1998) (Table 5).

Soil classification according to USDA Soil Taxonomy and World Reference Base (WRB) for Soil Resources

The mean annual soil temperatures are high $\left(>22^{\circ} \mathrm{C}\right)$ and nearly constant at $50 \mathrm{~cm}$ depth, indicating an hyperthermic soil temperature. On the basis of annual rainfall and monthly evapotranspiration/rainfall ratios, the soils have ustic moisture regime, the soils are classified as Entisols because there is little or no horizon development. These soils have no diagnostic horizon other than ochric. They are further classified as Psammets at the suborder because of coarser texture in all horizons. At the great group level, pedons 3,4 (Sokoto coversand) 5, and 6, (Illela coversand) are classified as Quartzipsamments because they have in the $0.02-2.0 \mathrm{~mm}$ fraction within the particle-size control section, a total of more than $90 \%$ by weighted average quartz (Table 4) while pedons 1 and 2 (Sangiwa coversand) are classified as Ustipsamments because of the ustic moisture regime. At the subgroup level, pedons 3, 4, 5 and 6, are classified as Ustic Quartzipsamments because of an ustic moisture regime. Pedons 1 and 2 are classified as Typic Ustipsamments because the soil satisfies most of the requirements of Typic concept of Ustipsamments which are fixed on sands that have deep ground water and a thick regolith.

According to the World Reference Base (WRB) for soil resources, the soils are classified as Arenosols at the soil group level because they have no diagnostic horizon other than ochric. The texture of the soils is coarsed to a depth of $100 \mathrm{~cm}$ in all the profiles. Pedons 3, 4, 6 and 4, are classified as Haplic Arenosols because of weakly developed coarse textured soil with simple, normal horizon sequence. Pedons 1 and 2 are classified as Dystric Arenosols because they have a base saturation (by $1 M$ $\mathrm{NH}_{4} \mathrm{OAc}$ ) of less than 50 percent in at least some part between 20 and $100 \mathrm{~cm}$ from the soil surface.

Management implications of the soil properties

The sandy nature of the soils may bring about problem of moisture stress and nutrient deficiency and consequently reduce the yields of some crops that have higher requirement for water and nutrients. Results also indicate that soil structure is weak. The soils therefore, require cultural/management practices that could improve soil structure such as the addition of crop residues, farmyard manure and provision of soil cover (planting cover crops, mulching etc.). The soils may not be suitable for irrigated agriculture because they may require great amount of water for irrigation due to their coarse texture. These soils may therefore be 
suitable for rain-fed agriculture. The chemical properties of the soils also revealed a low fertility status and therefore may require high nutrient inputs.

\section{Conclusion}

Soils on coversand are extensive in SokotoRima basin area of Sokoto State, sandy in nature and with poor structural development. The soils have a common problem of low inherent fertility, evidenced by low organic matter contents and CEC. In addition they are all acid; with reaction ranging from very strongly acid to slightly acid.

\section{REFERENCES}

Agbu, P.A., and A.G. Ojanuga, 1989. Properties and classification of soils of Dange area of Sokoto state, Nigeria. Samaru J. Agric. Res., 6: 37-46.

Ashaye, T.I. 1969. Sesquioxide status and particle size distribution in twelve Nigerian soils derived from sand stones; African soils: 14 (1 \&2): 85-95.

Ayolagha, G.A. 2001. Survey and Classification of Yenagoa-Meander belt soils in the Niger Delta. In Ojeniyi et al., (Eds.), Management of Wetlands Soils for Sustainable Agriculture and Environment. Proceedings of the $27^{\text {th }}$ annual conference of the SSSN 5-9 November, 2001 Calabar-Nigeria, pp1017.

Brady, N.C. and R.R. Weil, 2002. The Nature and Properties of Soils. Thirteenth edition. Prentice Hall. 960pp.

Brindley, G.W. 1980. Quantitative X-ray mineral analysis of clays. In: Brindley, G.W. and G. Brown (eds) Crystal Structure of Clay Minerals and Their X-ray Identification. Mineralogical Society, London, pp.411-138.

Deleeuw, P.N. 1966. Notes on the vegetation of the Rima Basin, Northern Nigeria.Geogr. J. 27(4), 477-487.

Donahue, R.L., M.W. Raymond and J.C. Chickluna. (Eds.). 1990. Soils: An Introduction to Soils and Plant Growth. Prentice-Hall of India. 667pp.

Esu, I.E. 1999. Fundamentals of Pedology, stirting Horden pub (Nig) ltd. 136pp.

Fanning, D.S. and M.C.B. Fanning, 1989. Soil Morphology, Genesis and Classification. John Wiley and Sons. Inc. U.S.A. 339pp.

FAO, 1998. World Reference Base for Soil Resources (FAO, ISRIC, ISSS). World Soil Resource Reports 84, FOA, Rome, Italy. $161 \mathrm{pp}$.

FDALR, 1985. The Reconnaissance Soil Survey of Sokoto State, Nigeria. Soil report. Federal Department of Agricultural Land Resources, Kaduna.

Gee, G.W., and J.W. Bauder, 1986. Particle-size analysis. In Methods of Soil Analysis. A.
Klute (ed) Part I. 2nd ed. Agron. Monogr. 9 ASA and SSSA, Madison, WI. p. 383-409.

Johns, W.D., R.E., Grim and W.F. Bradley, 1954. Quantitative estimation of clay minerals by diffraction methods. J. Sediment. Petrol. 24:242-251.

Jones, B. 1948. The sedimentary rocks of Sokoto province. Geological survey.

Jones, J.B. 2001. Laboratory Guide for Conducting Soil Tests and Plant Analysis. CRC Press LLC. 363 Pp.

Kogbe, C.A. 1976. Outline of the Geology of Illumenden Basin in Northwestern Nigeria in Geology of Nigeria. Elizabethan publ. Co. Lagos.

Kowal, J.M. and D.T. Knabe 1972. An agroclimatologically Atlas of the Northern States of Nigeria. Institute of Agric Res. Samaru Zaria.

Lavkulich, L.M. 1981. Methods Manual, Pedology Laboratory. Department of soil science, University of British Columbia, Vancouver.

Mclean, E.O. 1965. Aluminium. In C.A Black., D.D. Evans, J.L. White, L.E. Ensminger, and F.E. Clark, (eds). Methods of Soil Analysis. Part 2. Chemical and mineralogical properties. No.9. Am. Soc. Agron. 952-962.

Nelson, D.W. and E. Sommers, 1982. Total C, Organic matter. In A.L., Page, R.H. Miller and D.R. Keeney (Eds.). Methods of Soil Analysis. Part 2, Chemical and Microbiological Properties. $2^{\text {nd }}$ ed. Agronomy 9: 539-579.

Nwaka, G.I.C. 1990. Studies on dune soils of Borno State. Morphology, classification and physical properties. Annals of Borno 6/7:198-204

Nwokocha, C.C., F.O.R Akamigbo, and G.O. Chukwu, 2003. Characterization and evaluation of soils of Umuahia north local government area of Abia State, for agricultural production. In Ojeniyi et al., (Eds.), Land degradation, Agricultural Productivity and Rural Poverty:Environmental implications. Proceedings of the $28^{\mathrm{h}}$ annual conference of the SSSN 4-7 November, 2003 UmudikeNigeria, pp. 308-315.

Opuwaribo, E. and C.T.I. Odu. 1978. Ammonium fixation in Nigeria Soils: 5 Types of Clay minerals and relationships with ammonium fixation. Soil Sci. Soc. 25: 283-293.

Pugh, J.C., and King, R.C. 1952. Outline of the geomorphology of Nigeria. South African Geographical J. XXXIV

Raji, B.A., Esu, I.E. and V.O. Chude. 1997. The Mineralogy of Haplustults and Quartzipsamments derived from sand dunes, NW Nigeria. Pp 51-58. In B. R. Singh (Ed.), Management of Marginal Lands in Nigeria, 
proceedings, $23^{\text {rd }}$ Annual conference of the Soil Science of Nigeria (SSSN), at Sokoto, 2$5^{\text {th }} 1997$.

Schoeneberger, P.J., D.A. Wysocki, E.C. Benham., W.D.Broderson (Eds.). 2002. Field Book for Describing and Sampling Soils, Version 2.0. National Soil Survey Center, Natural Resources Conservation Service, U.S. Department of Agriculture, Lincoln, NE.

Soil Survey Staff, 2003. Key to Soil Taxonomy. United State Department of Agriculture, Natural Resource Conservation Service. Ninth edition. 332Pp.

Sombroek, W.G. 1971. Ancient levels of plinthisation in N.W. Nigeria. In Yaalon D.H. (ed) Paleopedology; origin, nature and dating of paleosols. Intern. Soc. of Soil Science and Israel university press, 329338.

Sombroek, W.G., and I.S. Zonneveld, 1971. Ancient dune fields and fluviatile deposits in the Rima-Sokoto River Basin (NW Nigeria). Soil Survey Paper no.5, Netherlands Soil Survey Institute, Wageningen. 109pp.
Van Wambeke, A.R. 1962. Criteria for classifying tropical soils by age. Journal of soil sci. 13: 124-132.

Yakubu, M. 2001. Survey, Classification and genesis of Soils of Kalambaina Area, Sokoto State, Nigeria. Unpubl. M.Agric Thesis. Post graduate school, UNAAB. $97 \mathrm{pp}$

Yakubu, M. and B.R. Singh (2001). Erosional losses of soils and nutrients from a dry land farm in Sokoto, Nigeria J of Agric. and Env. Vol.2. No 1 P 147-151

Yakubu, M. and S.S. Noma, A.A. Malami and B.Z Abubakar, 2006. Socio-economic survey on the impact of sand dunes in Gidan Kaura village, Sokoto State Nigeria. In M.C. Madukwe, Changing perspective in extension innovation system in Nigeria, proceedings of Agricultural Extension Society of Nigeria (AESON) UNAAB, Abeokuta, $3^{\text {rd }}-6^{\text {th }}$ April 2006. 